\title{
Дослідження витрати палива автосамоскидами в умовах Омелянівського кар'єру
}

\author{
(Представлення: к.т.н., доц.. Шлапак В.О.)
}

\begin{abstract}
Оскільки вплив циклічної діяльності на споживання палива вантажними автомобілями при відкритих гірничих роботах у літературі не розглядається, тому пропонується методика оцінки цих ефектів. У цъьому дослідженні вимірювалося паливо, яке було спожито за один цикл роботи автосамоскида. Цикл роботи складається з основних етапів: завантаження, маневрування, транспортування, розвантаження та повернення в вихідне положення. Кожен із компонентів циклу пов'язаний із певною витратою палива. Тому функціональна залежність між компонентами циклу (як незалежні змінні) та кількістю споживаного палива за ијикл (як залежна змінна) визначає частку кожного компонента у загальній витраті палива автомобіля. Хоча виробники автосамоскидів пропонують приблизні оцінки витрат палива для різних моделей та розмірів вантажівок, існують значні невизначеності щзодо фактичних показників споживання палива, які обумовлені спещифічними умовами роботи. Специфічні умови (якість доріг тощо) призводять до значних відхилень у фактичному споживанні палива щзодо оцінок виробника. Недостатня оцінка потреби кар'єру в паливі призводить до значних труднощів у прийнятті рішення про бюджет кар'єру. Для того, щзоб надати достовірні та конкретні оцінки споживання палива для вантажівок, у иььому дослідженні оброблені статистичні дані з Омелянівського щеєбеневого кар 'єру. У цььому підході, в першу чергу, враховуються варіації спожсивання палива, які обумовлені конкретними умовами видобутку. Ця мета досягається використанням достатньо великої бази статистичних даних про споживання палива.
\end{abstract}

Ключові слова: витрата палива; моделювання; умови роботи; ичкл роботи; автосамоскиди.

Вступ. Майже третина загального обсягу палива, яке було спожито та викидів парникових газів пов'язано 3 використанням важких дизельних автомобілів. Тому моделювання споживання палива кар'єрним транспортом (та викидів парникових газів) має першорядне значення як для органів охорони навколишнього середовища. У результаті було опубліковано значну кількість публікацій 3 моделювання/аналізу споживання палива автомобілем. В останні роки дослідження моделювання енергії транспортних засобів були зосереджені переважно на легкових автомобілях. Наприклад, в публікації [1] здійснено аналіз оцінки життєвого циклу в китайській промисловості легких автомобілів. Автори вважають, що викиди парникових газів і споживання енергії можуть бути додатково зменшені при збільшенні вмісту Al в автомобілі. Мураторі та ін. [2] використовували моделювання для оцінки споживання енергії для особистого транспорту. Хайям і Баб Хадіашар [3] пропонують інтелектуальну систему керування енергією 3 використанням контролерів нечіткої логіки для легких гібридних електромобілів.

Хао та ін. [4] оцінили вплив нової китайської політики на споживання енергії та викиди парникових газів легкових автомобілів. Однак є декілька останніх публікацій, які присвячені конкретному питанню 3 моделювання енергії кар'єрних автосамоскидів. У працях [5-12] наведено умови ведення на гірничих підприємствах. Уайт та ін. [13] проаналізували статистичні дані про споживання палива та змоделювали попит на енергію вантажівок в Ірландії. Чжао та ін. [14] стверджують, що покращення ефективності двигуна, аеродинамічного опору та опору коченню деяких типів вантажних автомобілів у Китаї може підвищити енергетичну ефективність вантажівок.

3 іншого боку, кар'єрні транспортні роботи відрізняється від інших галузей промисловості. Цикл завантаження та транспортування гірничих матеріалів включає основні етапи навантаження, транспортування, розвантаження, маневрування та повернення до пунктів завантаження. Кар'єрні дороги мають більш жорстку поверхню, ніж автомобільні дороги. Вантажопідйомність кар'єрних автосамоскидів може перевищувати 350 тон, а кількість пилу, що утворюється, зазвичай вище. Крім того, операція характеризується коротшими циклами, ніж транспортування в інших галузях промисловості. Такі умови транспортування при видобутку корисних копалин призводять до специфічних випадків із споживанням 
палива, що потребують спеціального дослідження. Кекоєвич і Комленович [15] вивчали вплив потужності та факторів навантаження двигуна на споживання палива. Шуу та ін. [16] запропонували загальну модель для порівняння споживання енергії для самоскидів у кар'єрах. Дисуреат [17] використовував регресійні та штучні нейронні мережі для прогнозування споживання дизельного палива та електроенергії. Богунович та ін. [18] розробили інтегровану систему середовища даних для аналізу споживання енергії на кар'єрі. Однак вплив циклічності на витрату палива для вантажних автомобілів за цикл не вивчався у літературі. У нещодавньому дослідженні [19] встановлено зв'язок між споживанням палива для кар'єрних автомобілів та циклічною діяльністю, моделювання відбувалося в рамках підходу нейронної мережі. Однак через природу нейронних мереж не було побудовано жодного функціонального зв'язку між незалежними змінними (наприклад, навантаженням, транспортуванням тощо) та витратою палива. Це дослідження спирається на попередню публікацію та вносить свій внесок у цю сферу, пропонуючи функціональний зв'язок між змінними. Також визначаються норми витрати палива для різних режимів роботи вантажівок. Крім того, у цьому дослідженні результати порівнюються з рекомендованою виробником вантажівок формулою. Дослідження застосовує часткову регресію найменших квадратів та авторегресивну інтегральну ковзну середню для прогнозування споживання палива на основі циклічної активності (наприклад, часу навантаження, часу перевезення вантажу тощо).

Мета статті - на основі фактичних даних витрати палива автосамоскидами в умовах Омелянівського кар'єру створити математичну модель витрати палива автосамоскидами БелАЗ 548.

Викладення основного матеріалу. Оскільки вплив циклічної діяльності на споживання палива вантажними автомобілями при наземних гірничодобувних роботах у літературі не розглядається, тому пропонується методологія оцінки цих ефектів. У цьому підході кількість палива, спожитого за один повний цикл навантажувальних робіт, належить до компонентів циклу. Повний цикл складається 3 основних етапів завантаження, маневрування, транспортування, розвантаження та повернення. Кожен із компонентів циклу пов'язаний із певною часткою загального витраченого палива за один повний цикл навантаження. Тому функціональна залежність між компонентами циклу (як незалежні змінні) та кількістю споживаного палива за цикл (як залежна змінна) визначає частку кожного компонента у загальній витраті палива автомобіля. Хоча виробники вантажних автомобілів пропонують приблизні оцінки витрат палива для різних моделей та розмірів вантажівок, існують значні невизначеності щодо фактичних показників споживання палива, які обумовлені специфічними умовами різних майданчиків. Специфічні умови (якість доріг тощо) призводять до значних відхилень у фактичному споживанні палива щодо оцінок виробника. Недостатня/надмірна оцінка енергетичної потреби кар'єру призводить до значних труднощів у прийнятті рішення про бюджет кар'єру. Для того, щоб надати достовірні та конкретні оцінки споживання палива для вантажівок, у цьому дослідженні оброблені статистичні дані з Омелянівського щебеневого кар'єру. У цьому підході насамперед враховуються варіації споживання палива, які обумовлені конкретними умовами видобутку. Ця мета досягається використанням достатньо великої бази статистичних даних про споживання палива.

Для обробки даних був використаний метод часткової регресії найменших квадратів, який в основному використовується для моделювання лінійної регресії між кількома залежними змінними та (множинними) незалежними змінними. Перевагою цього методу перед звичайною лінійною множинною регресією $\epsilon$ те, що він поєднує основні функції моделей регресування, аналіз основних компонентів та аналіз канонічної кореляції [20]. У контексті лінійних регресій рішення найменших квадратів для рівняння (1) задається рівнянням (2):

$$
\begin{aligned}
& Y=X B+\varepsilon, \\
& B=\left(X^{T} X\right)^{-1} X^{T} Y .
\end{aligned}
$$

Часто проблема полягає в тому, що $\mathrm{X}^{\mathrm{T}} \mathrm{X} \epsilon$ єдиним через те, що кількість змінних (стовпців) у $\mathrm{X}$ перевищує кількість об'єктів (рядків). Метод часткової регресії найменших квадратів обходить це шляхом розкладання X на ортогональні оцінки (Т) та навантаження (Р) (3) [21]:

$$
X=T R .
$$

Крім того, метод часткової регресії найменших квадратів регресує Y не на X, на першому стовпці балів. Метою цього методу є включення інформації щодо X та Y у визначення балів та навантажень. Оцінки та навантаження вибираються таким чином, щоб максимально описати коваріантність між X та Y.

Дані про споживання палива були проаналізовані та змодельовані за допомогою методики інтегрованої моделі авторегресії в контексті аналізу часових рядів. Підготовка/попередня обробка даних $\epsilon$ одним із перших і найважливіших кроків аналізу часових рядів. Основні статистичні дані щодо споживання палива зведені в таблиці 2. Розроблені [22] моделі за допомогою інтегрованої моделі авторегресії забезпечують статистично надійний підхід до прогнозування часових рядів. Моделі спрямовані на опис автокореляцій у даних [23]. У моделі за допомогою інтегрованої моделі авторегресії майбутнє значення змінної має бути лінійною комбінацією минулих значень і помилок, виражених у вигляді рівняння (4):

$$
y_{t}=\vartheta_{0}+\varphi_{1} y_{t-1}+\varphi_{2} y_{t-2}+\ldots+\varphi_{p} y_{t-p}+\varepsilon_{t}-\vartheta_{1} \varepsilon_{t-1}-\vartheta_{2} \varepsilon_{t-2}-\ldots-\vartheta_{q} \varepsilon_{t-q},
$$


де $y_{t}$ - це фактичне значення, $\varepsilon_{t}$ - це випадкова помилка в момент часу $\mathrm{t}, \varphi_{i}$ та $\vartheta_{i}$ - коефіцієнти, а $p$ і $q-$ цілі числа, які часто називають поліномами авторегресії та поліномами ковзного середнього, відповідно.

Наприклад, інтегровані моделі авторегресії можна представити у вигляді рівняння (5):

$$
y_{t}=\vartheta_{0}+\varphi_{1} y_{t-1}+\varepsilon_{t}-\vartheta_{1} \varepsilon_{t-1} \text {. }
$$

Дані були отримані для більше ніж 1000 циклів перевезення щебеневої сировини на Омелянівському щебеневому кар'єрі. Дослідними вантажівками були вантажівки 3 жорсткою рамою БелАз 540, які були обладнані бортовими системами реєстрації даних і завантажувалися екскаватором ЕКГ-5А (ковш 5 м³). База даних включала масу гірської породи, яка транспортується, умови транспортування та витрату палива за цикл. У таблиці 1 наведено узагальнену статистику всіх змінних за допомогою критерія Груббса. Незалежними змінними було корисне навантаження, час завантаження, час затримки простою, час завантаження, час порожнього руху та порожній час простою.

Залежною (вихідною) змінною був об’єм палива, який спожитий за цикл. Метод часткової регресії найменших квадратів був використаний для моделювання та прогнозування споживання палива на основі даних системи керування інформацією, яка наведена у таблиці 1.

Таблиия 1

Статистика змінних, які пов'язані із споживанням палива на кар'єрних самоскидах

\begin{tabular}{|c|c|c|c|}
\hline & Мінімум & Максимум & Середні \\
\hline \multicolumn{4}{|c|}{ Незалежний } \\
\hline Корисне навантаження, т & 24 & 52 & 42 \\
\hline Час завантаження, с & 52 & 320 & 52 \\
\hline Час простою (завантажений), с & 30 & 350 & 280 \\
\hline Час у дорозі (завантажений), с & 32 & 856 & 260 \\
\hline Час у дорозі (порожній), с & 28 & 769 & 329 \\
\hline Час простою (порожній), с & 0 & 6000 & 17,1 \\
\hline \multicolumn{2}{|c|}{ Залежний } \\
\hline Витрата палива, л/цикл & 13,2 & 56,3 & \\
\hline
\end{tabular}

Результат прогнозування витрати палива за 100 циклів ілюструється на рисунку 1. Сто циклів (10 \%) 3 наявних 1000 циклів були випадково вибрані і використані для тестування моделі. Для того, щоб вивчити модель, ці цикли не були використані на етапі побудови моделі.

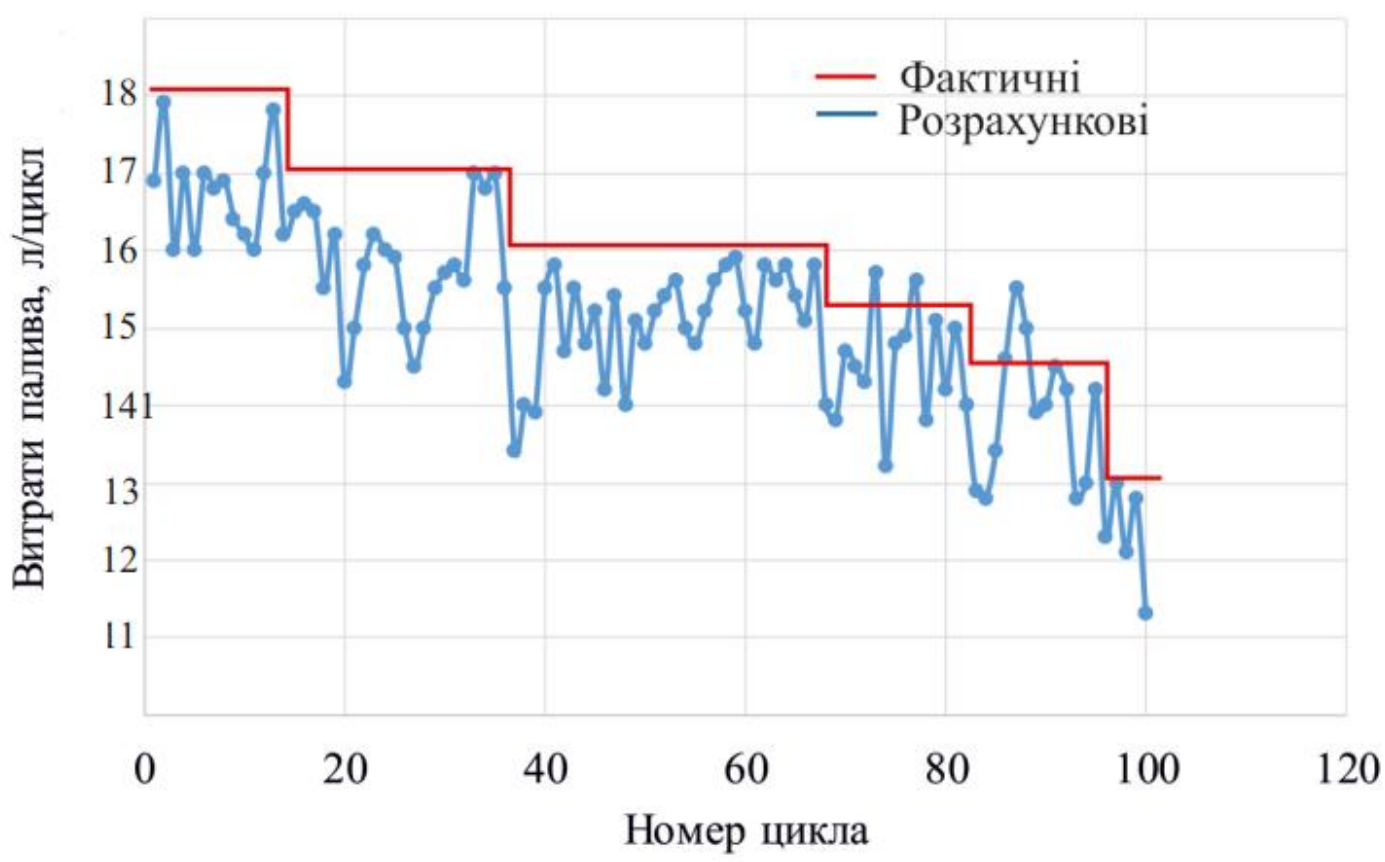

Рис. 1. Фактичні та прогнозовані витрати палива за 100 ичиклів 
Середньоквадратична помилка та середня абсолютна помилка у відсотках для набору даних тестування становили 1,17 та 6,01 \% відповідно. Прогнозування грунтується на лінійній комбінації минулих спостережень, яка потребує стаціонарного ряду без будь-якої конкретної тенденції в даних.

3 іншого боку, інтегрована модель авторегресії - модель і методологія аналізу тимчасових рядів [24]. Тому прогнозування грунтується на лінійній комбінації спостережень, яка потребує стаціонарного ряду без будь-якої конкретної тенденції в даних. Широко використовуваним методом передачі даних у стаціонарний ряд є застосування диференціації. У більшості випадків достатньо одного або двох порядків диференціації для підготовки даних для методу. Параметр d - це порядок диференціації в комбінованій моделі (тобто інтегрована модель авторегресії (p, d, q)). Застосування інтегрованої моделі авторегресії до сезонних даних потребує подальшого розмежування в сезонній частині. У цьому випадку модель називається сезонною і представлена (p, d, q) (P, D, Q) S з порядком сезонного диференціювання D i циклом S, P i Q є авторегресивні та ковзні середні складові сезонної частини даних. У цьому випадку було вибрано $\mathrm{D}=1$ для врахування сезонності моделі. Найкращі параметри p, q, P та Q моделі були отримані на основі обох виправлений інформаційний критерій [25] та критерій Шварца Байєса [26].

Таблиия 2

Статистика споживання палива

\begin{tabular}{|c|c|}
\hline Статистика & Витрата палива (л/цикл) \\
\hline Кількість спостережень & 998 \\
\hline Мінімум & 13,2 \\
\hline Максимум & 36,3 \\
\hline 1-й квартиль & 13,3 \\
\hline Медіана & 15,1 \\
\hline 3-й квартиль & 18,4 \\
\hline Середнє значення & 14,1 \\
\hline
\end{tabular}

Низькі значення середньої абсолютної похибки за період прогнозування на 100 циклів показують хороші показники інтегрованої моделі авторегресії при прогнозуванні споживання палива. Прогноз споживання палива за 100 циклів імітує поведінку кривої з відносно вузькими межами 95 \%, як показано на рисунку 2.

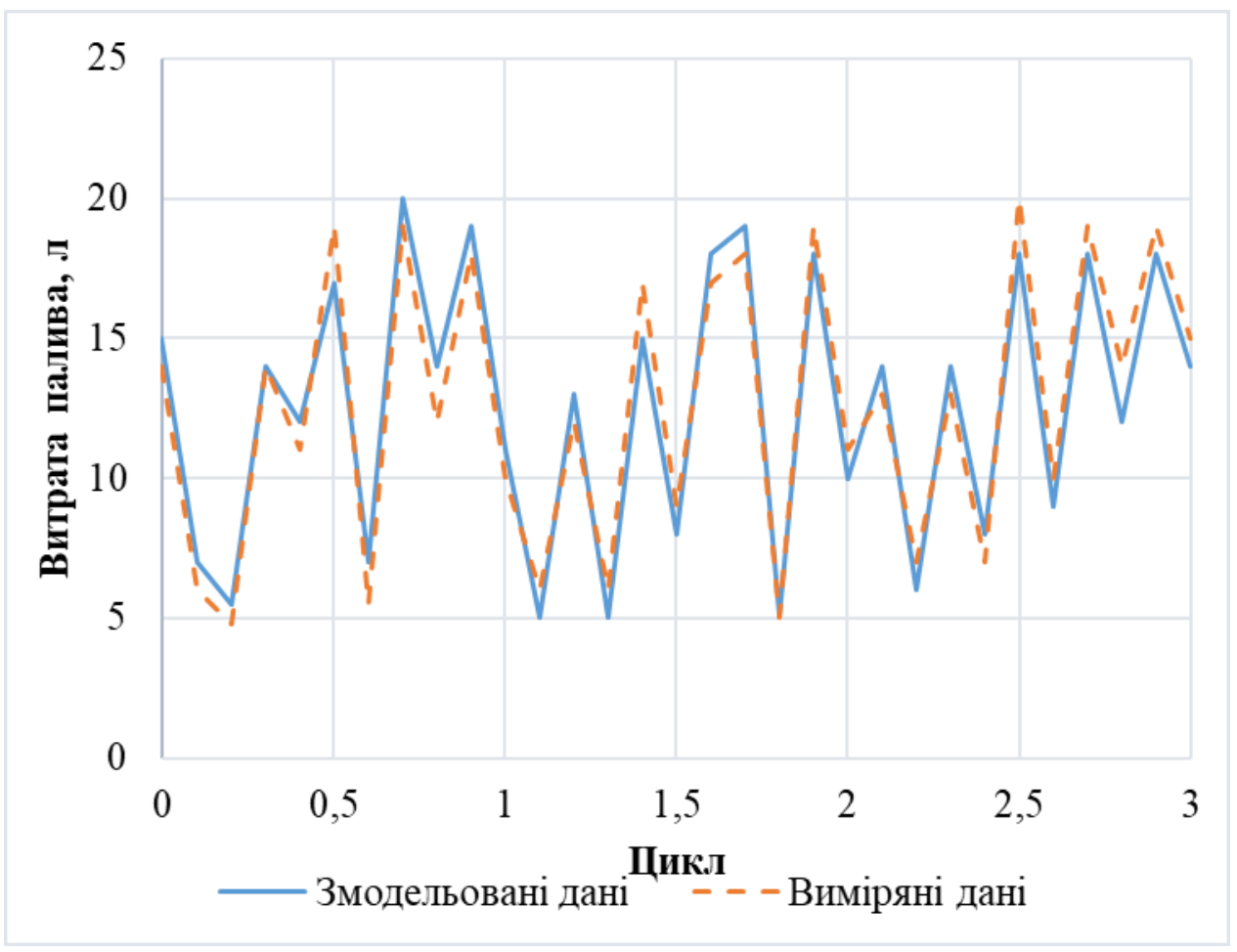

Рис. 2. Витрати палива за один цикл під час руху автосамоскида 
Діагностика моделі - це остання частина моделювання за допомогою інтегрованої моделі авторегресії, яку можна виконати шляхом огляду залишків. Залишки моделі досліджувалися за допомогою тесту Люнга та Бокса [9] на предмет задоволення стану ряду білого шуму. Ряд білого шуму - це послідовність статистично незалежних та однаково розподілених випадкових величин.

Аналіз експериментальних даних про витрати палива показав, що час порожнього простою вантажівки $\epsilon$ основним фактором непотрібних витрат палива. Оскільки черги вантажівок біля мехлопат $є$ ключовою причиною порожнього простою, варто докласти зусиль, щоб зменшити черги. Основні причини збільшення простою порожнього простою є: відсутність рівної поверхні уступу, нерівномірно розкладений негабарит, незручне розташування відвалів, а також відсутність диспетчеризації. Окрім технічних параметрів, навички водія вантажівки і екскаватора та стиль водіння мають прямий вплив на споживання палива.

Змінні, що демонструють найбільшу позитивну кореляцію з витратою палива - це час порожнього руху, час навантаження та час порожнього простою. Час навантаження та порожнього руху залежить від відстаней перевезення та максимально допустимих швидкостей. Стан дорожнього покриття транспорту, нахили та повороти визначають максимальну швидкість. Таким чином, кращі дорожні умови мають значний вплив на споживання палива, скорочуючи час навантаження та час порожнього руху. Третя змінна, яка позитивно корелює з витратою палива - це порожній час простою. Експлуатаційні вантажівки або простоюють у чергах з мехлопатами та дробарками, або перевозять гірську породу.

Модель регресії представлена у рівнянні (6). Коефіціснти змінних часу у рівнянні (6) дорівнюють нормі витрати палива у різних режимах роботи в літрах/цикл. Відповідні норми споживання представлені в літрах за секунду / 1000 циклів роботи. PL вказано у тонах, а всі інші незалежні змінні у рівнянні (6) - у секундах.

$$
\begin{aligned}
& \Pi=1,37071+0,00483 \mathrm{~B}+0,00399 t_{\text {зав }}+0,0048 t_{\text {пор.пр }}+0,01472 t_{\text {пор.рух }}+ \\
& +0,00378 t_{\text {зав.пр }}+0,0420 t_{\text {зав.рух }}, \text { л/цикл }
\end{aligned}
$$

де П - витрата палива (літри за цикл); В - корисний вантаж (тони); $t_{\text {зав }}$ - час завантаження (c); $t_{\text {пор.пр }}-$ час

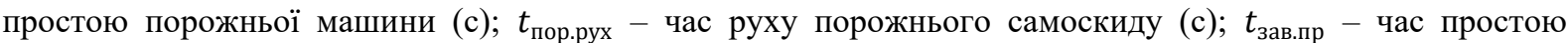
завантаженого автосамоскида (c); $t_{\text {зав.рух }}$ час руху завантаженого автосамоскида (c).

Виробники вантажівок надають оцінки споживання палива на годину для різних потужностей двигунів і коефіцієнтів навантаження $\left(K_{\mathrm{H}}\right)$. $\mathrm{K}_{\mathrm{H}}$ - це частина максимальної доступної потужності вантажівки, яка потрібна для виконання певної операції. Наприклад, $K_{\mathrm{H}}$ для перевезення вантажів еквівалентна потужності, яка необхідна для перевезення певної кількості вантажу на певну відстань з урахуванням умов експлуатації, таких як стан дорожнього покриття, швидкість, навички та стиль водіння оператора, погодні умови, ухили дороги тощо. Залежно від умов експлуатації К обладнання використовують $K_{\mathrm{H}}$ для приблизної оцінки витрати палива в різних режимах роботи. У цьому дослідженні були використані дані фактичного споживання палива парком вантажних автомобілів в умовах Омелянівського кар'єру. Однією з переваг моделі, запропонованої в цій роботі, є те, що оцінки $є$ більш точними та специфічними для конкретного місця, ніж ті, що пропонуються виробниками, які базуються на одній незалежній змінній $\mathrm{K}_{\mathrm{H}}$ для різних потужностей/типів двигунів. Зрозуміло, мета формули виробників - дати дуже приблизну оцінку витрати палива.

Таким чином запропонована модель має тісну кореляцію з виміряними даними. Усі інші змінні мають ті ж значення та одиниці, що й у рівнянні (6). Хоча можливі перешкоди в мережі доріг/ухили та сезонні умови не були безпосередньо розглянуті у рівнянні (6), їх вплив сильно корелює з часом циклу. Оскільки база даних містить оперативні дані про перевезення протягом одного року, наслідки зміни відстані, сезонні коливання та зміна мережі (протягом одного року) вже включені до бази даних. Ці дані $\epsilon$ репрезентативними для одного року роботи конкретного дослідження. У загальному підсумку, хоча методи були використані на конкретному прикладі, вони застосовні до інших операцій у Омелянівському кар'єрі.

Висновки. Інтегрована модель авторегресії дала практичне уявлення про основні причини споживання палива. Був побудований функціональний зв'язок між циклом роботи та кількістю спожитого палива за цикл. Простої автосамоскида найбільше вплинули на зміну споживання палива за цикл.

\section{Список використаної літератури:}

1. Potential for reducing GHG emissions and energy consumption from implementing the aluminum intensive vehicle fleet in China / J.D. Du, W.J. Han, Y.H. Peng, C.C. Gu // Energy. - 2010. - Vol. 35, Issue 12. - P. 4671-4678.

2. Highly-resolved modeling of personal transportation energy consumption in the United States / M.Muratori, M.J. Moran, E.Serra, G.Rizzoni // Energy. - 2013. - Vol. 58. - P. 168-177.

3. Khayyam H. Adaptive intelligent energy management system of plug-in hybrid electric vehicle / H.Khayyam, A.BabHadiashar // Energy. - 2014. - Vol. 69. - P. 319-335

4. Scenario analysis of energy consumption and greenhouse gas emissions from China's passenger vehicles / H.Hao, Z.Liu, F.Zhao et al. // Energy. - 2015. - Vol. 91. - P. 151-159. 
5. Korobiichuk V. Study of ultrasonic characteristics of Ukrainian red granites at low temperatures Systems / V.Korobiichuk // Control and Information Technology. -Warsaw. - pp. 20-21.

6. Закусило Р.В. Засоби ініціювання промислових зарядів вибухових речовин : монографія / Р.В. Закусило, В.Г. Кравещь, В.В. Коробійчук. - Житомир : ЖДТУ, 2011. - 212 с.

7. Дослідження впливу буровибухових робіт на якість блочної продукції кар'єру на основі визначення геометричних характеристик iї тріщинуватості / В.В. Коробійчук, Р.В. Соболевський, Ю.О. Подчашинський та ін. // Вісник ЖДТУ. - 2007. - № 3 (42). - С. 143-150.

8. Коробійчук В.В. Залежність внутрішньопорового тиску від пружних властивостей природного каменю / В.В. Коробійчук // Вісник ЖДТУ. - 2012. - № 1 (60). - С. 123-126.

9. Ljung G.M. On a measure of a lack of fit in time series models / G.M. Ljung, G.E.P. Box // Biometrika. - 1978. Vol. 65 (2). - P. 297-303.

10. European integration: treatment of stone processing enterprises waste in Ukraine / V.V. Korobiichuk, O.M. Sidorov, R.V. Sobolevskyi et al. // Вісник ЖДТУ. - 2017. - № 1 (79). - С. 182-190.

11. Shamrai V.I. Management of waste of stone processing in the framework of Euro integration of Ukraine / V.I. Shamrai, V.V. Korobiichuk, R.V. Sobolevskyi // Вісник ЖДТУ. - 2017. - № 2 (80). - Т. 1. - C. 234-239.

12. Динаміка споживання паливно-мастильних матеріалів самоскидами на Омелянівському родовищі гранітів / Л.А. Ковалевич, В.Г. Левицький, Д.М. Білобров та ін. // Технічна інженерія. - 2021. - № 1 (87). - С. 142-148.

13. Whyte $K$. Modelling HGV freight transport energy demand in Ireland and the impacts of the property construction bubble / K. Whyte, H.E. Daly, B.P.O. Gallachoir // Energy. - 2013. - Vol. 50. - P. 245-251.

14. Zhao H. Analysis of Class 8 truck technologies for their fuel savings and economics / H.Zhao, A.Burke, M.Miller // Transp Res Part D Transp Environ. - 2013. - Vol. 23. - P. 55-63.

15. Kecojevic $V$. Haul truck fuel consumption and $\mathrm{CO}_{2}$ emission under various engine load conditions / V.Kecojevic, D. Komljenovic // Min Eng. - 2010. - Vol. 62 (12). - P. 44-48.

16. Sahoo L.K. Benchmarking energy consumption for dump trucks in mines / L.K. Sahoo, S.Bandyopadhyay, R.Banerjee // Appl Energy. - 2014. - Vol. 113. - P. 1382-1396.

17. Dessureault S. Data mining, mining data: energy consumption modelling / S.Dessureault // CIM Bull. - 2007. Vol. 100. - P. 1-7.

18. Analysis of energy consumption in surface coal mining / D.Bogunovic, V.Kecojevic, V.Lund et al. // SME Trans. 2009. - Vol. 326. - P. 79-87.

19. Siami-Irdemoosa E. Prediction of fuel consumption of mining dump trucks: a neural networks approach / E.SiamiIrdemoosa, S.R. Dindarloo // Appl Energy. - 2015. - Vol. 151. - P. 77-84.

20. Forecasting the transport energy demand based on PLSR method in China / M.Zhang, H.Mu, G.Li, Y.Ning // Energy.2009. - Vol. 34 (9). - P. 1396-1400.

21. Mevik B-H. The pls package: principal component and partial least squares regression in R. J Stat Softw / B-H.Mevik, R.Wehrens // Journal of Statistical Software - 2007. - Vol. 18, Issue 2. - P. 1-23.

22. Box G.E.P. Time series analysis, forecasting and control / G.E.P. Box, G.Jenkins. - San Francisco : Holden-Day, 1970. $-553 \mathrm{p}$.

23. Hyndman R.J. Forecasting: principles and practice / R.J. Hyndman, G.Athanasopoulos. - Monash University, Australia. - 2013 [Electronic resource]. - Access mode : http://otexts.org/fpp/.

24. Pai P-F. A hybrid ARIMA and support vector machines model in stock price forecasting / P-F.Pai, C-S.Lin // Omega. - 2005. - Vol. 33, Issue 6. - P. 497-505.

25. Akaike H. A new look at the statistical model identification / H.Akaike // IEEE Trans Automatic Control. - 1974. Vol. 19 (6). - P. 716-23.

26. Schwarz G.E. Estimating the dimension of a model / G.E. Schwarz // Ann Stat. - 1978. - Vol. 6 (2). - P. $461-464$.

\section{References:}

1. Du, J.D., Han, W.J., Peng, Y.H. and Gu, C.C. (2010), «Potential for reducing GHG emissions and energy consumption from implementing the aluminum intensive vehicle fleet in China», Energy, Vol. 35, Issue 12, pp. 4671-4678.

2. Muratori, M., Moran, M.J., Serra, E. and Rizzoni, G. (2013), «Highly-resolved modeling of personal transportation energy consumption in the United States», Energy, Vol. 58, pp. 168-177.

3. Khayyam, H. and Bab-Hadiashar, A. (2014), «Adaptive intelligent energy management system of plug-in hybrid electric vehicle», Energy, Vol. 69, pp. 319-335.

4. Hao, H., Liu, Z., Zhao, F. et al. (2015), «Scenario analysis of energy consumption and greenhouse gas emissions from China's passenger vehicles», Energy, Vol. 91, pp. 151-159.

5. Korobiichuk V. «Study of ultrasonic characteristics of Ukrainian red granites at low temperatures Systems» Control and Information Technology, Warsaw, pp. 20-21.

6. Zakusylo, R.V., Kravec', V.G. and Korobijchuk, V.V. (2011), Zasoby inicijuvannja promyslovyh zarjadiv vybuhovyh rechovyn, monografija, ZhDTU, Zhytomyr, $212 \mathrm{p}$.

7. Korobijchuk, V.V., Sobolevs'kyj, R.V., Podchashyns'kyj, Ju.O. et al. (2007), «Doslidzhennja vplyvu burovybuhovyh robit na jakist' blochnoi' produkcii' kar'jeru na osnovi vyznachennja geometrychnyh harakterystyk i'i' trishhynuvatosti», Visnyk ZhDTU, No. 3 (42), pp. 143-150.

8. Korobijchuk, V.V. (2012), «Zalezhnist' vnutrishn'oporovogo tysku vid pruzhnyh vlastyvostej pryrodnogo kamenju», Visnyk ZhDTU, No. 1 (60), pp. 123-126.

9. Ljung, G.M. and Box, G.E.P. (1978), «On a measure of a lack of fit in time series models», Biometrika, Vol. 65 (2), pp. 297-303. 
10. Korobiichuk, V.V., Sidorov, O.M., Sobolevskyi, R.V. et al. (2017), «European integration: treatment of stone processing enterprises waste in Ukraine», Visnyk ZhDTU, No. 1 (79), pp. 182-190.

11. Shamrai, V.I., Korobiichuk, V.V. and Sobolevskyi, R.V. (2017), «Management of waste of stone processing in the framework of Euro integration of Ukraine», Visnyk ZhDTU, No. 2 (80), Vol. 1, pp. 234-239.

12. Kovalevych, L.A., Levyc'kyj, V.G., Bilobrov, D.M. et al. (2021), «Dynamika spozhyvannja palyvno-mastyl'nyh materialiv samoskydamy na Omeljanivs'komu rodovyshhi granitiv», Tehnichna inzhenerija, No. 1 (87), pp. 142-148.

13. Whyte, K., Daly, H.E. and Gallachoir, B.P.O. (2013), «Modelling HGV freight transport energy demand in Ireland and the impacts of the property construction bubble», Energy, Vol. 50, pp. 245-251.

14. Zhao, H., Burke, A. and Miller, M. (2013), «Analysis of Class 8 truck technologies for their fuel savings and economics», Transp Res Part D Transp Environ, Vol. 23, pp. 55-63.

15. Kecojevic, V. and Komljenovic, D. (2010), «Haul truck fuel consumption and $\mathrm{CO}_{2}$ emission under various engine load conditions», Min Eng, Vol. 62 (12), pp. 44-48.

16. Sahoo, L.K., Bandyopadhyay, S. and Banerjee, R. (2014), «Benchmarking energy consumption for dump trucks in mines», Appl Energy, Vol. 113, pp. 1382-1396.

17. Dessureault, S. (2007), «Data mining, mining data: energy consumption modelling», CIM Bull, Vol. 100, pp. 1-7.

18. Bogunovic, D., Kecojevic, V., Lund, V. et al. (2009), «Analysis of energy consumption in surface coal mining», $S M E$ Trans, Vol. 326, pp. 79-87.

19. Siami-Irdemoosa, E. and Dindarloo, S.R. (2015), «Prediction of fuel consumption of mining dump trucks: a neural networks approach», Appl Energy, Vol. 151, pp. 77-84.

20. Zhang, M., Mu, H., Li, G. and Ning, Y. (2009), «Forecasting the transport energy demand based on PLSR method in China», Energy, Vol. 34 (9), pp. 1396-1400.

21. Mevik, B-H. and Wehrens, R. (2007), «The pls package: principal component and partial least squares regression in R. J Stat Softw», Journal of Statistical Software, Vol. 18, Issue 2, pp. 1-23.

22. Box, G.E.P. and Jenkins, G. (1970), Time series analysis, forecasting and control, Holden-Day, San Francisco, 553 p.

23. Hyndman, R.J. and Athanasopoulos, G. (2013), «Forecasting: principles and practice», Monash University, Australia, [Online], available at: http://otexts.org/fpp/

24. Pai, P-F. and Lin, C-S. (2005), «A hybrid ARIMA and support vector machines model in stock price forecasting», Omega, Vol. 33, Issue 6, pp. 497-505.

25. Akaike, H. (1974), «A new look at the statistical model identification», IEEE Trans Automatic Control, Vol. 19 (6), pp. 716-23.

26. Schwarz, G.E. (1978), «Estimating the dimension of a model», Ann Stat, Vol. 6 (2), pp. 461-464.

Ковалевич Людмила Анатоліївна - старший викладач кафедри маркшейдерії Державного університету «Житомирська політехніка».

https://orcid.org/0000-0001-9158-2576.

Наукові інтереси:

- транспортні технології;

- відкриті гірничі роботи.

E-mail: kovalevych.zt@gmail.com.

Леонець Ірина Володимирівна - аспірант Державного університету «Житомирська політехніка». Наукові інтереси: https://orcid.org/0000-0002-6572-681X.

- переробка вторинних матеріалів

- процеси відкритих гірничих робіт

Лебля Микола Вікторович - аспірант Державного університету «Житомирська політехніка». Наукові інтереси:

- маркшейдерські роботи;

- технології транспортування гірничої маси.

Дубінчук Денис Олегович - аспірант Державного університету «Житомирська політехніка».

Наукові інтереси:

- маркшейдерські роботи;

- технології транспортування гірничої маси.

Куницька Марина Сергї̈вна - аспірант Державного університету «Житомирська політехніка». https://orcid.org/0000-0002-2649-0939.

Наукові інтереси:

- маркшейдерські роботи;

- технології транспортування гірничої маси. 